\title{
The efficacy of lyticase and $\beta$-glucosidase enzymes on biofilm degradation of Pseudomonas aeruginosa strains with different gene profiles
}

\author{
Maryam Banar ${ }^{1}$, Mohammad Emaneini ${ }^{1}$, Reza Beigverdi ${ }^{1}$, Rima Fanaei Pirlar ${ }^{1}$, Narges Node Farahani ${ }^{1}$, \\ Willem B. van Leeuwen ${ }^{2}$ and Fereshteh Jabalameli ${ }^{1^{*}}$
}

\begin{abstract}
Background: Pseudomonas aeruginosa is a nosocomial pathogen that causes severe infections in immunocompromised patients. Biofilm plays a significant role in the resistance of this bacterium and complicates the treatment of its infections. In this study, the effect of lyticase and $\beta$-glucosidase enzymes on the degradation of biofilms of $P$. aeruginosa strains isolated from cystic fibrosis and burn wound infections were assessed. Moreover, the decrease of ceftazidime minimum biofilm eliminating concentrations (MBEC) after enzymatic treatment was evaluated.

Results: This study demonstrated the effectiveness of both enzymes in degrading the biofilms of $P$. aeruginosa. In contrast to the lyticase enzyme, $\beta$-glucosidase reduced the ceftazidime MBECs significantly $(P<0.05)$. Both enzymes had no cytotoxic effect on the A-549 human lung carcinoma epithelial cell lines and A-431 human epidermoid carcinoma cell lines.

Conclusion: Considering the characteristics of the $\beta$-glucosidase enzyme, which includes the notable degradation of $P$. aeruginosa biofilms and a significant decrease in the ceftazidime MBECS and non-toxicity for eukaryotic cells, this enzyme can be a promising therapeutic candidate for degradation of biofilms in burn wound patients, but further studies are needed.
\end{abstract}

Keywords: Pseudomonas aeruginosa, $\beta$-Glucosidase, Lyticase, Biofilm

\section{Background}

Pseudomonas aeruginosa is a nosocomial pathogen that causes severe infections in patients with cancer, cystic fibrosis (CF), and burn injuries [1, 2]. It accounts for about $10 \%$ of nosocomial infections [3]. Biofilm production of $P$. aeruginos $a$ is an essential factor in the persistence of infections [4]. The biofilm matrix of $P$. aeruginosa is composed of various exopolysaccharides (alginate, Psl, and Pel), extracellular DNA, and proteins [5, 6]. Alginate is a polymer containing mannuronic acid and guluronic acid [7], which is produced by the mucoid phenotype of $P$. aeruginosa in the lungs of CF

\footnotetext{
* Correspondence: jabalamf@tums.ac.ir

${ }^{1}$ Department of Microbiology, School of Medicine, Tehran University of Medical Sciences, Tehran, Iran

Full list of author information is available at the end of the article
}

patients and associated with chronic infections and antibiotic resistance $[4,8]$. Several different genes are involved in encoding exopolysaccharides alginate, Psl, and Pel. Twelve structural genes located on the alg $\mathrm{D}$ gene operon are involved in the biosynthesis of alginate. The algD gene encodes a GDP- mannose dehydrogenase enzyme converting GDPmannose to the GDP-mannuronic acid that controls the alginate production [6]. The Psl polysaccharide constitutes a repeating pentamer of D-mannose, L-rhamnose, and Dglucose monosaccharides [9]. Studies revealed that Psl is involved in cell-cell and cell-surface interactions of bacteria in biofilm and makes the scaffold for biofilm formation. It also mediates the resistance of biofilm to phagocytosis and the host immune clearance $[9,10]$. The Psl is encoded by a 15 co-transcribed gene cluster (pslA to $p s l O$ ), that 11 out of 
15 genes are necessary for Psl production [11]. The $p s l B$ gene encodes Phosphomannose Isomerase/ GDP-mannose pyrophosphorylase (PMI-GMP), which is a bifunctional enzyme and contributes to the synthesis of Psl precursors. Studies have shown that $p s l \mathrm{~B}$ mutants can still produce the Psl polysaccharide. The $p s l \mathrm{D}$ gene encodes for a periplasmic protein that mediates the transmission of Psl polymer across the periplasmic space. Mutations in this gene result in a defect in Psl production [9]. Pel is a glucose-rich polysaccharide that plays a role in biofilm formation, maintenance, and resistance of biofilm against antibiotics, especially aminoglycosides [12].. The Pel operon (pelA-G) encodes seven proteins involved in the production of Pel polysaccharide, which all of them are important in Pel biosynthesis. The pelF gene encodes a cytoplasmic protein that is a glycosyltransferase and involves the transmission of sugar units of Pel as well as the Pel polymerization [13].

Because biofilm in $P$. aeruginosa is a relevant factor that confers resistance to environmental stresses, phagocytic defenses, antimicrobial agents, and xenobiotics [14-17], and due to the increasing intrinsic resistance of this bacterium to many antibiotics, treatment of its infections are limited [13]. So researchers are trying to find new therapeutic approaches against infections of this bacterium [18]. In recent years, the anti-biofilm ability of enzymes against biofilms of $P$. aeruginosa was studied $[6,17]$. For example, deoxyribonuclease (DNase) enzyme that has a specific effect on degrading the DNA in the mucus or sputum of CF patients $[19,20]$ is used as a therapy for $\mathrm{CF}$ patients with the commercial name of Pulmozyme [21]. Alginate lyase is another enzyme that can degrade the biofilm of $P$. aeruginosa [22] and is a promising candidate for the treatment of infections caused by mucoid strains of this bacterium [23].

The ability of lyticase and $\beta$-glucosidase enzymes to degrade $\beta(1 \rightarrow 3)$ and $\beta(1 \rightarrow 4)$ bonds between the glucose units $[24,25]$ and their probable effects on Psl and Pel polysaccharides were the reasons for choosing these enzymes.

This study aimed to investigate the destructive effect of lyticase and $\beta$-glucosidase enzymes on biofilms of clinical strains of $P$. aeruginosa.

\section{Results}

Among the $122 P$. aeruginosa clinical strains isolated from independent patients with CF or burn wound infections, a total of 11 strains were selected based on their unique gene profiles (presence or absence of the biofilm exopolysaccharides encoding genes: $p s l \mathrm{~B}, p s l \mathrm{D}$, $a l g \mathrm{D}$, and $p e l \mathrm{~F}$ ) and phenotypic traits (the state of biofilm formation and susceptibility to amikacin and ceftazidime) (Table 1). It was tried to select strains from all gene profiles (there were eight different gene profiles) with the ability to generate strong or moderate biofilms
Table 1 Gene profiles and phenotypic characteristics of $P$. aeruginosa strains that were evaluated in this study $(n=11)$

\begin{tabular}{|c|c|c|c|}
\hline Strain & Gene profile & Resistance pattern & Biofilm production \\
\hline$\overline{\mathrm{BR}} 1^{\mathrm{a}}$ & pelF $F^{+}, \operatorname{alg} D^{+}, p s / B^{+}, p s \mid D^{+}$ & - & strong \\
\hline $\mathrm{BR} 2$ & $p e l F^{+}, \operatorname{alg} D^{+}, p s\left|B^{+}, p s\right| D^{+}$ & - & strong \\
\hline$C F 1^{b}$ & $p e l F^{+}, \operatorname{alg} D^{+}, p s\left|B^{+}, p s\right| D^{+}$ & - & strong \\
\hline BR3 & pelF, alg $D^{-}, p s I B^{-}, p s \mid D^{-}$ & $A K, C A Z$ & weak \\
\hline BR4 & pelF, alg $D^{-}, p s\left|B^{-}, p s\right| D^{-}$ & $A K, C A Z$ & strong \\
\hline BR5 & pelF $, \operatorname{alg} D^{-}, p s I B^{-}, p s I D^{-}$ & $A K, C A Z$ & strong \\
\hline BR6 & pelF, alg $D^{+}, p s / B^{+}, p s I D^{+}$ & AK & strong \\
\hline CF & $p e l F^{+}, \operatorname{alg} D^{-}, p s\left|B^{+}, p s\right| D^{+}$ & - & strong \\
\hline CF3 & pelF $F^{+}$alg $D^{+}, p s \mid B^{-}$ & - & strong \\
\hline BR7 & $p e l F^{+}, \operatorname{alg} D^{+}, p s\left|B^{-}, p s\right| D^{-}$ & C & strong \\
\hline BR8 & pelF, alg $D^{+}, p s\left|B^{-}, p s\right| D^{-}$ & $A K, C A Z$ & moderate \\
\hline
\end{tabular}

AK Amikacin, CAZ Ceftazidime

${ }^{\mathrm{a} B R}$; Burn strain

${ }^{\mathrm{b}} \mathrm{CF}$; Cystic fibrosis strain

and susceptibility to amikacin and ceftazidime. However, since there were few strains in some groups, these criteria were not applicable in some cases. For example, although strains BR3, 4, 5, and 6 were resistant to amikacin and ceftazidime, because of their unique gene profiles were enrolled in the enzymatic analysis.

For example, the degradative effect of serial dilutions of lyticase and $\beta$-glucosidase enzymes on the biofilm of strain BR1 is shown in Fig. 1. Both enzymes had a destructive effect on biofilms and reduced OD (optical density) values $(P<0.05)$. The most effective concentrations of lyticase and $\beta$-glucosidase enzymes on the biofilm were 2.5 units $\mathrm{mL}^{-1}$ and 0.05 units $\mathrm{mL}^{-1}$, respectively (Fig. 1). The effect of the most effective concentrations of enzymes on the biofilms of $P$. aeruginosa strains with different gene profiles was evaluated using crystal violet and colony counting methods (Table 2, Fig. 2, and Fig. 3). As shown, there was an agreement between the results of the two assays, and the two examined enzymes destroyed the biofilm and resulted in the reduction of the colony-forming units (CFU) (Data are available in Additional file 1).

After testing the effect of selective concentrations of enzymes on $P$. aeruginosa biofilms, the SEM analysis (scanning electron microscopy) was applied to visualize the biofilm degrading effect of the selected concentration of $\beta$-glucosidase enzyme ( 0.05 units $\mathrm{mL}^{-1}$ ) (Fig. 4).

The bactericidal effects of enzymes on $P$. aeruginosa planktonic cells were investigated. Accordingly, the $\beta$ glucosidase was toxic and killed bacterial cells so that no turbidity was seen in the wells, and no colonies were present (MIC and MBC for all strains $<0.025$ units $\mathrm{mL}^{-1}$ ). But the lyticase enzyme had no bactericidal effect, and bacterial cells grew after treatment with this enzyme (MIC and MBC for all strains $>50$ units $\mathrm{mL}^{-1}$ ). 


\section{1. $\beta$-glucosidase}

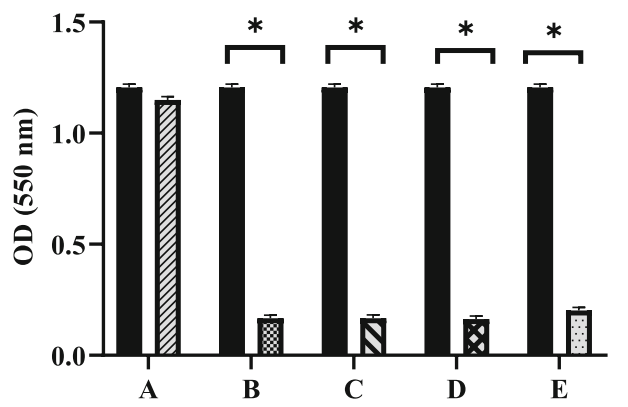

No enzyme treatment

Enzyme concentrations (units $\mathrm{mL}^{-1}$ )

\section{Lyticase}

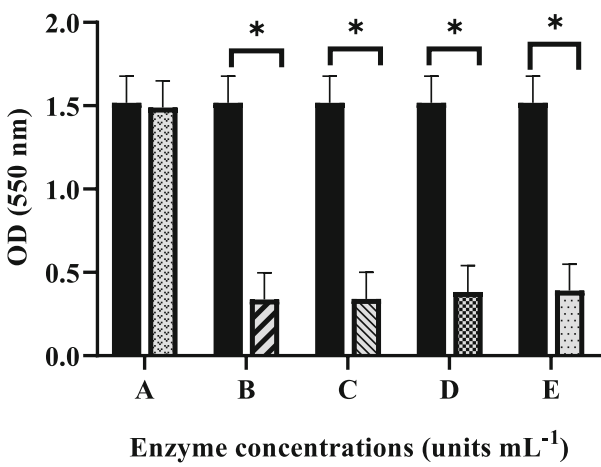

Fig. 1 The effects of serial dilutions of (1) enzyme $\beta$-glucosidase [0.025 (a), 0.05 (b), 0.1 (c), 0.2 (d), and 0.4 (e) units $\mathrm{mL}^{-1}$ ] and (2) enzyme lyticase $\left[1.25\right.$ (a), 2.5 (b), 5 (c), 10 (d), and 25 (e) units $\left.\mathrm{mL}^{-1}\right]$ on biofilms of $P$. aeruginosa strain BR1 that were evaluated by CV assay. The experiment was done once in triplicates. Error bars represent standard deviation (SD). Asterisks indicate the statistically significant difference with control (no enzyme treatment) $\left({ }^{*} P<0.05\right)$

Table 2 Effect of selected concentrations of enzymes lyticase $\left(2.5\right.$ units $\left.\mathrm{mL}^{-1}\right)$ and $\beta$-glucosidase $\left(0.05\right.$ units $\left.\mathrm{mL}^{-1}\right)$ on the biofilm of $P$. aeruginosa strains with different gene profiles that were assessed by CV assay

\begin{tabular}{|c|c|c|c|c|}
\hline \multirow[b]{2}{*}{ Strain } & \multicolumn{2}{|l|}{ Lyticase (2.5 units $\left.\mathrm{mL}^{-1}\right)$} & \multicolumn{2}{|c|}{$\beta$-glucosidase $\left(0.05\right.$ units $\left.\mathrm{mL}^{-1}\right)$} \\
\hline & Before enzyme treatment & After enzyme treatment & Before enzyme treatment & After enzyme treatment \\
\hline $\mathrm{BR} 1^{\mathrm{a}}$ & Strong & Weak & Strong & Weak \\
\hline BR2 & Strong & Moderate & Strong & Weak \\
\hline BR3 & Weak & Negative & Weak & Negative \\
\hline BR4 & Strong & Negative & Strong & Weak \\
\hline BR5 & Strong & Negative & Strong & Negative \\
\hline BR6 & Strong & Moderate & Strong & Weak \\
\hline BR7 & Strong & Moderate & Strong & Moderate \\
\hline BR8 & Moderate & Moderate & Moderate & Moderate \\
\hline $\mathrm{CF} 1^{\mathrm{b}}$ & Strong & Weak & Strong & Moderate \\
\hline CF2 & Strong & Weak & Strong & Negative \\
\hline CF3 & Strong & Moderate & Strong & Weak \\
\hline
\end{tabular}

${ }^{\mathrm{a}} B R$ Burn strain

${ }^{\mathrm{b}}$ CF Cystic fibrosis strain 


\section{a. Lyticase}
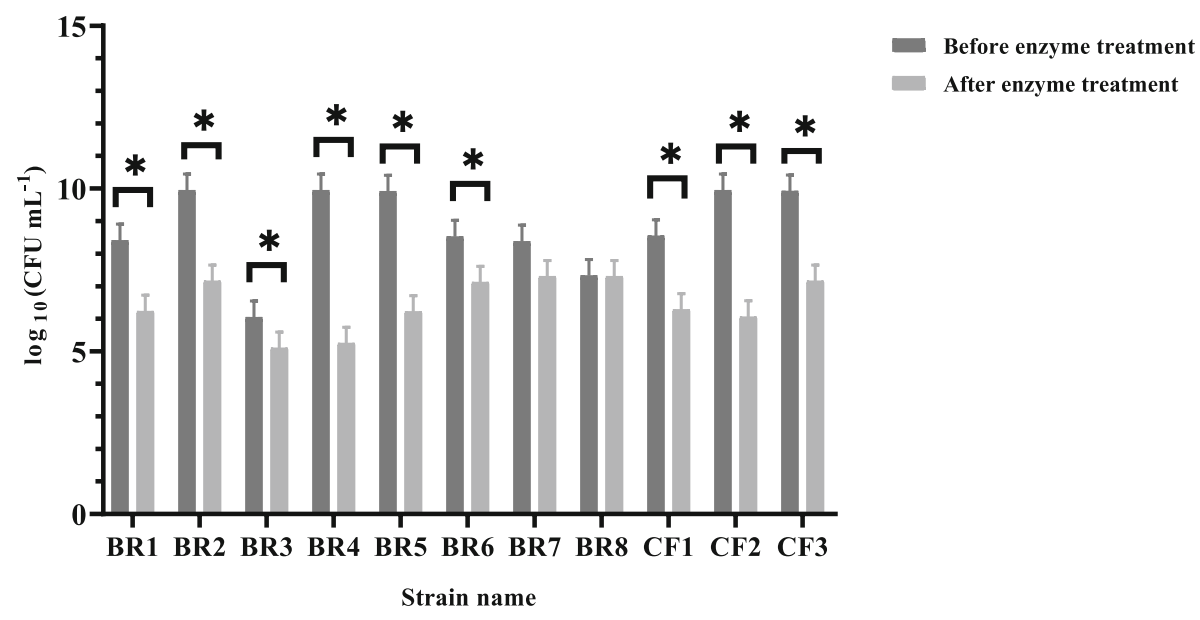

After enzyme treatment

\section{b. $\beta$-glucosidase}

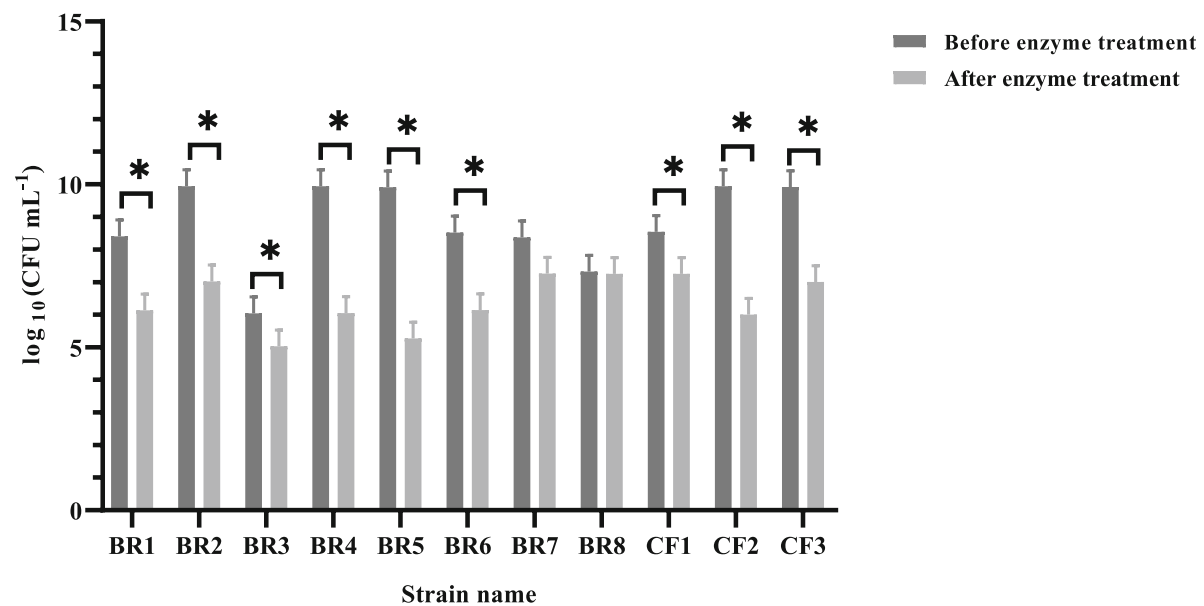

Fig. 2 The effects of selected concentrations of enzymes (a) lyticase $\left(2.5\right.$ units $\left.\mathrm{mL}^{-1}\right)$ and (b) $\beta$-glucosidase $\left(0.05\right.$ units $\left.\mathrm{mL}^{-1}\right)$ against biofilm embedded $P$. aeruginosa strains with different gene profiles that were determined by colony counting technique. Error bars represent standard deviation (SD). Asterisks indicate the statistically significant difference before and after enzyme treatment $\left({ }^{*} P<0.05\right)$

Amongst 11 strains, six susceptible strains to ceftazidime and amikacin in their planktonic states (BR1, 2, 7, and CF1, 2, 3) were selected to estimate the minimum inhibitory concentration (MIC) and the minimum biofilm eliminating concentrations (MBEC) of these antibiotics. Strain BR6, which was resistant to amikacin, and strains BR3, 4, 5 and 8, which were resistant to both amikacin and ceftazidime, were not involved in the experiment (Table 3). Results demonstrated that biofilm formation led to increasing ceftazidime resistance significantly $(P<0.05)$; however, strains in the biofilm state remained susceptible to the amikacin.

The effects of the simultaneous use of lyticase or $\beta$ glucosidase with ceftazidime on the MBEC values of ceftazidime are shown in Table 4. Results showed that lyticase had no significant effect on the MBEC values of ceftazidime $(P>0.05)$. However, $\beta$-glucosidase significantly reduced the ceftazidime MBECs $(P<0.05)$.

The cytotoxicity assay revealed that lyticase and $\beta$ glucosidase had no significant effect on mitochondrial activity and cell viability $(P>0.05)$ (Fig. 5) (Data are available in Additional file 1).

\section{Discussion}

In recent years, enzymes have been considered as potential anti-biofilm and debriding agents [26, 27]. There are several examples of enzymes used as antibiofilm agents in treating the infections or wound debridement, including debridase (bromelain- derived), collagenase (clostridio peptidase A), trypsin, streptokinase, lysozyme, fibrinolysin and dispersin B [28-33]. These enzymes can be used in debridement of 


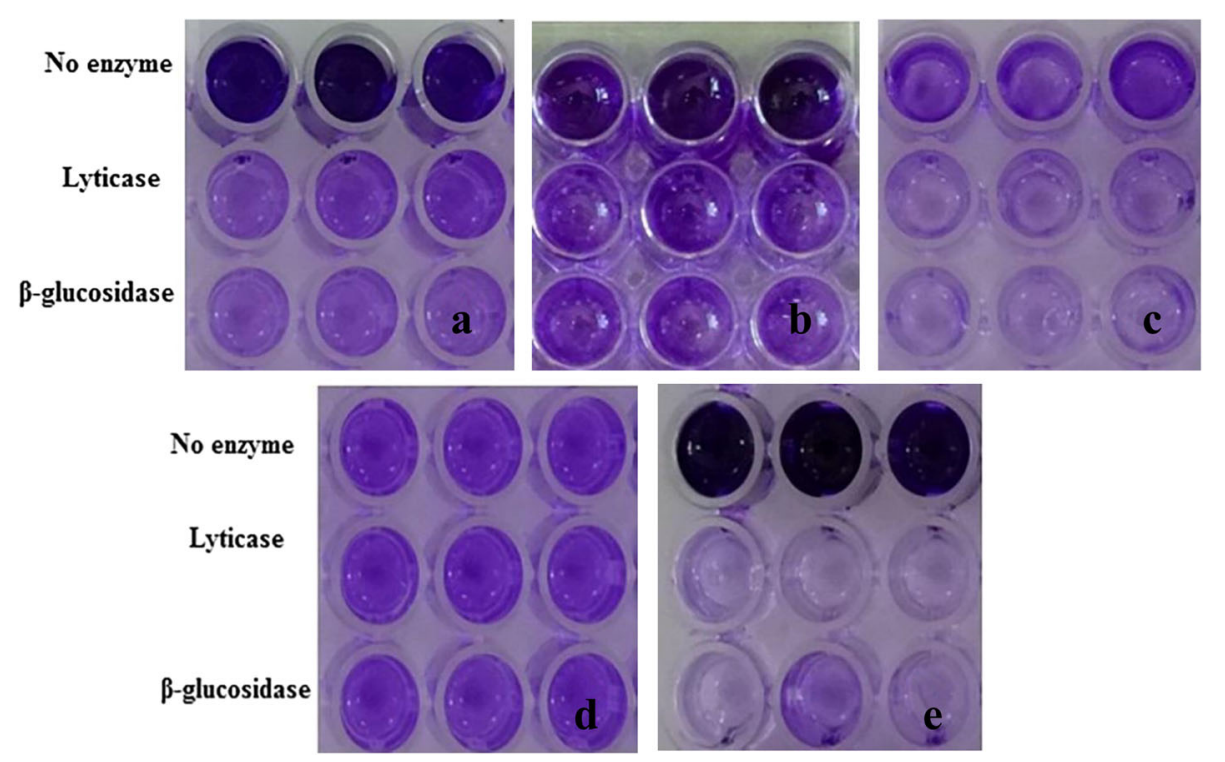

Fig. 3 The effects of selected concentrations of enzymes lyticase $\left(2.5\right.$ units $\left.\mathrm{mL}^{-1}\right)$ and $\beta$-glucosidase $\left(0.05\right.$ units $\left.\mathrm{mL}^{-1}\right)$ against biofilm embedded P. aeruginosa strains with different gene profiles: $\mathbf{a}$ strain BR1, $\mathbf{b}$ strain BR7, $\mathbf{c}$ strain BR3, $\mathbf{d}$ strain BR8, and e strain CF3

wounds and removing barriers that debilitate wound healing, such as devitalized tissues, scars, and bacterial biofilms [30-33].

In this study, the influence of lyticase and $\beta$ glucosidase enzymes on biofilms of different $P$. aeruginosa strains was investigated. The results demonstrated that both lyticase and $\beta$-glucosidase enzymes degraded the biofilms of $P$. aeruginosa strains with various gene profiles, altered the state of biofilms, and decreased the CFUs significantly. However, they did not destroy the biofilms of the two strains BR7 and BR8 with gene profiles of $p e l F^{+}, \operatorname{alg} D^{+}, p s l B^{-}, p s l D^{-}$and $p e l F^{-}, \operatorname{alg} D^{+}, p s l B^{-}$, $p s l D^{-}$, respectively $(P>0.05)$. Regarding the gene profiles of strain BR7, it seems that this strain lacks Psl polysaccharide in its biofilm structure, which is one of the substrates of lyticase and $\beta$-glucosidase enzymes. Neither of the tested enzymes destroyed the biofilm of strain BR8 since these enzymes did not have any effect on the structure of alginate.

The $\beta$-glucosidase enzyme was highly efficient on ceftazidime MBECs and reduced the MBEC 2 to 128 times. But, the lyticase enzyme was not efficient and reduced the ceftazidime MBECs only by a factor two. Probably, the lyticase degradation fragments had an inhibitory effect and prevented the ceftazidime activity on the bacterial cells in the remaining biofilm. For that reason, the ceftazidime MBECs showed no significant changes. On the other hand, $\beta$-glucosidase had a bactericidal effect, in contrast to lyticase. Maybe this is another reason that the lyticase did not reduce the antibiotic resistance of bacterial biofilms.
According to the toxicity assay, both enzymes were non-toxic and did not affect the mitochondrial cell functions. Future studies concerning the assessment of the toxicity of these enzymes on primary cell cultures and animal models are needed.

There are some limitations to this study. First, the total sample size was small (122 strains) and when strains classified based on their gene profiles, the number of strains in some groups was very few. This point can affect statistical analysis and conclusion. Second, the expression of biofilm encoding genes ( $p s l B, p s l D$, algD, and $p e l F$ ) and the structure of biofilm in selected strains was not evaluated. Therefore, the effect of enzymes on the biofilm of strains with different gene profiles was discussed based on the assumptions.

\section{Conclusion}

In conclusion, considering the features of the $\beta$ glucosidase enzyme, including notable degradation of $P$. aeruginosa biofilms and a significant decrease in the ceftazidime MBECs and non-toxicity for eukaryotic cells, this enzyme can be a promising candidate as an antibiofilm agent. So it is recommended to perform further studies on it. Given the polymicrobial nature of biofilms, it is suggested to investigate the efficacy of the $\beta$ glucosidase enzyme on the degradation of mixed-species biofilms. Moreover, the effect of lyticase enzyme on the MBECs of other antibiotics can be evaluated in the subsequent studies. Also, in future studies, the effects of these enzymes on the development of immune responses in the body and on the skin and respiratory tract normal flora, should be examined. 

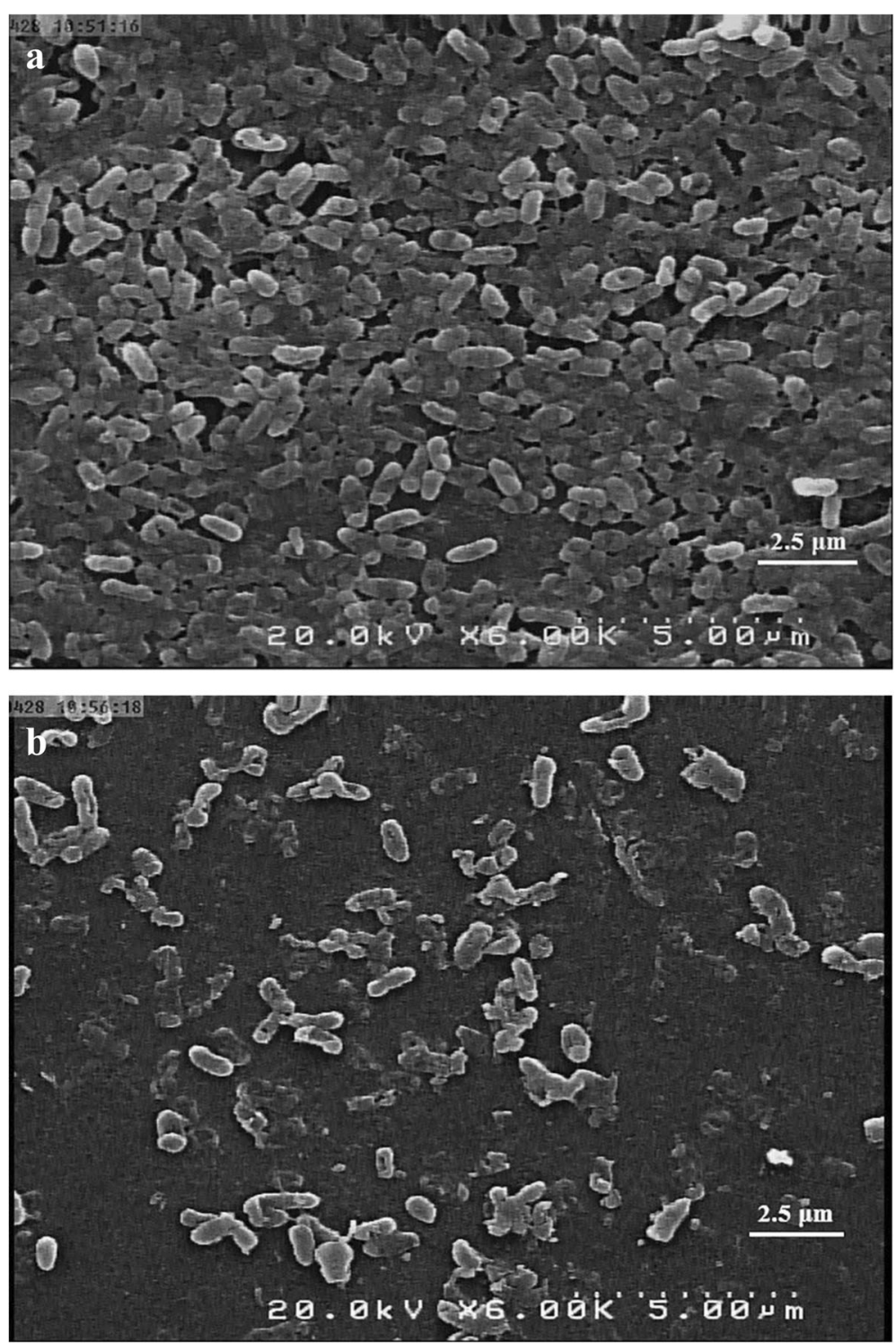

Fig. 4 The scanning electron microscopy (SEM) images of $P$. aeruginosa biofilms (strain BR3). a Untreated control biofilm. $\mathbf{b}$ After $1 \mathrm{~h}$ treatment with enzyme $\beta$-glucosidase ( 0.05 units $\mathrm{mL}^{-1}$ ) (6000x magnification)

Table 3 Comparison of the results of Minimum Inhibitory Concentration (MIC) and Minimum Biofilm Eliminating Concentrations (MBECs) for P. aeruginosa strains

\begin{tabular}{llllll}
\hline Strain & \multicolumn{2}{l}{ Amikacin $\left(\mu \mathrm{gL}^{-1}\right)$} & & \multicolumn{2}{l}{ Ceftazidime $\left(\mu \mathrm{gL}^{-1}\right)$} \\
\cline { 2 - 3 } & MIC & MBEC & & MIC & MBEC \\
\hline BR1 & 4 & 16 & & 2 & 1024 \\
BR2 & 4 & 16 & & 2 & 1024 \\
BR7 & 8 & 8 & & 2 & 1024 \\
CF1 & 8 & 8 & & 1 & 512 \\
CF2 & 2 & 8 & & 2 & 512 \\
CF3 & 8 & 16 & & 4 & 1024 \\
\hline
\end{tabular}

Table 4 The combined effects of enzymes and ceftazidime on the MBEC values of ceftazidime

\begin{tabular}{llll}
\hline Strain & $\begin{array}{l}\text { Ceftazidime (CAZ) } \\
\left(\mu \mathrm{mL}^{-1}\right)\end{array}$ & $\begin{array}{l}\text { CAZ+ lyticase } \\
\left(\mu \mathrm{g} \mathrm{mL}^{-1}\right)\end{array}$ & $\begin{array}{l}\text { CAZ }+\beta-\text { glucosidase } \\
\left(\mu \mathrm{gL}^{-1}\right)\end{array}$ \\
\hline BR1 & 1024 & 1024 & 512 \\
BR2 & 1024 & 512 & 8 \\
BR7 & 1024 & 512 & 32 \\
CF1 & 512 & 512 & 128 \\
CF2 & 512 & 512 & 16 \\
CF3 & 1024 & 512 & 8 \\
\hline
\end{tabular}




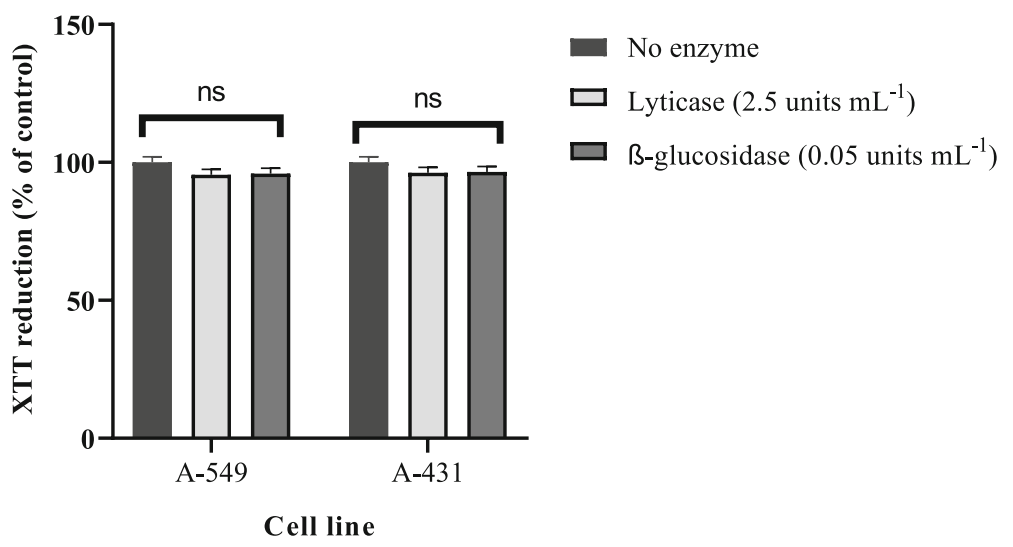

Fig. 5 Influence of the most effective concentration of enzymes lyticase $\left(2.5\right.$ units $\left.\mathrm{mL}^{-1}\right)$ and $\beta$-glucosidase $\left(0.05 \mathrm{units}_{\mathrm{mL}} \mathrm{m}^{-1}\right)$ on the viability of the A-549 human lung carcinoma epithelial cell lines and A-431 human epidermoid carcinoma cell lines after $24 \mathrm{~h}$ incubation. The experiment was done two times in duplicates. Error bars represent standard deviation (SD). The ns represent non-significant difference compared with control (no enzyme treatment) $(P>0.05)$

\section{Methods}

\section{Bacterial strains}

A total number of $122 P$. aeruginosa clinical strains which were isolated from independent patients with $\mathrm{CF}$ or burn wound infections were collected from clinical microbiology laboratory of a tertiary hospital in Tehran, Iran. Strains were identified as $P$. aeruginosa using standard biochemical tests, including Gram stain, oxidase, catalase, oxidation-fermentation (OF), and the Kligler Iron Agar (KIA) tests [34]. Eleven out of 122 strains based on their gene profiles (presence or absence of the biofilm exopolysaccharides encoding genes: $p s l B$, $p s l D, \operatorname{alg} D$, and $p e l F$ ) and phenotypic traits (the state of biofilm formation and susceptibility to amikacin and ceftazidime) were selected and included in the study.

\section{Antimicrobial susceptibility testing}

Amikacin and ceftazidime are the antibiotics of choice that are used for the treatment of CF or burn patients with $P$. aeruginosa infection. The susceptibility of $P$. aeruginosa to both antibiotics was assessed using the disk diffusion agar method according to the Clinical and Laboratory Standards Institute (CLSI) guidelines [35]. Escherichia coli ATCC 25922 was used as the quality control of the test.

\section{Molecular detection of genes encoding biofilm exopolysaccharides}

The presence of genes encoding biofilm exopolysaccharides in $P$. aeruginosa (algD, pelF, pslB, and pslD) was established by the PCR (polymerase chain reaction) assay, as previously described [6]. The specific oligonucleotide primer F-5' -GCG.AGT.TTC.TCC.TCA.ACA.CC-3' and R-5' -CGA.CCG.TAG.ATG.TCG.TTG.AA-3' was used for detection of the $p s l B$ gene.

\section{Biofilm analysis}

The biofilm-forming capacity of the strains was determined in triplicate using a colorimetric microtiter plate assay (CV assay) as described previously [6]. Pseudomonas aeruginosa ATCC 27853 and sterile broth were used as the positive and negative controls, respectively. The bacterial cells were inoculated with turbidity equal to $0.5 \mathrm{McFarland}$ standard $\left(1.5 \times 10^{8} \mathrm{CFU} \mathrm{mL}^{-1}\right)$. The ODs of the wells was measured at $550 \mathrm{~nm}$ using a microplate reader (Anthos Labtec instruments, type: 22550). All the assays were done in triplicate and repeated three times for each strain.

Three standard deviations above the mean absorbance of negative control were considered as cut-off OD $\left(\mathrm{OD}_{\mathrm{C}}\right)$. Biofilm formation was classified into four different groups using the following formulas: If $\mathrm{OD}<\mathrm{ODc}$, the biofilm was not formed (negative), If ODc $<\mathrm{OD}<$ $2 \mathrm{xODc}$, the biofilm was weak, If $2 \mathrm{xODc}<\mathrm{OD}<4 \mathrm{xODc}$, the biofilm was moderate. If $4 \times \mathrm{XDc}<\mathrm{OD}$, the biofilm was strong.

\section{Determination of the enzyme activity}

In this study, the degradable effect of the two enzymes $\beta$-glucosidase and lyticase was evaluated. The $\beta$ glucosidase enzyme is purified from almonds and is involved in the hydrolysis of $\beta$-glycosidic bonds connecting carbohydrate residues in $\beta$-D-glycosides. It converts cellobiose and cello-oligosaccharides to glucose [24].

The lyticase enzyme is purified from gram-positive bacteria, Arthrobacter luteus, which is a member of the Micrococcaceae family. It hydrolyzes poly- $\beta(1 \rightarrow 3)$-glucose bonds such as yeast cell wall glucan and generates spheroplasts from fungi for transformation. It also is used for DNA extraction from yeast cells [25]. 
The biofilm detachment potency of the enzymes was determined by Kaplan et al., [36]. In short, the wells were rinsed once with sterile normal saline, and different concentrations of lyticase enzyme [1.25, 2.5, 5, 10 and 25 units $\left.\mathrm{mL}^{-1}\right]$ and $\beta$-glucosidase enzyme $[0.025,0.05$, $0.1,0.2$ and 0.4 units $\mathrm{mL}^{-1}$ ] were added to the wells [24]. After incubation for $1 \mathrm{~h}$ at $37 \mathrm{C}$, wells contents were removed and were washed three times with normal saline and stained with crystal violet (CV assay) [6]. In our study, biofilms without any enzymatic treatment and medium with neither bacteria nor enzyme were considered as test controls. The assay was performed once in triplicate for each enzyme concentration. Further studies were performed by the most effective concentrations of each enzyme. Enzymes were purchased from Sigma Aldrich (St Louis, USA).

The destructive effect of selected concentrations of each enzyme on the biofilms of $P$. aeruginosa strains was also determined by colony counting technique [37]. For each strain and enzyme, the assay was done once in triplicate. The effect of the selected concentration of $\beta$-glucosidase $\left(0.05\right.$ units $\left.\mathrm{mL}^{-1}\right)$ on the biofilm of $P$. aeruginosa was observed by a scanning electron microscope (SEM) as described by Nemoto K et al., [19].

The bactericidal effect of the enzymes on planktonic cells of $P$. aeruginosa was evaluated as described before [6]. Briefly, a serial dilutions of enzymes lyticase $\left[1.25,2.5,5,10,25\right.$, and 50 units $\left.\mathrm{mL}^{-1}\right]$ and $\beta$ glucosidase $[0.025,0.05,0.1,0.2,0.4$, and 0.8 units $\mathrm{mL}^{-1}$ ] were added to the wells containing $100 \mu \mathrm{L}$ of Mueller-Hinton broth and bacterial suspension (final inoculum density of $10^{8} \mathrm{CFU} \mathrm{mL}^{-1}$ ). The selected concentrations of the enzymes were in the range of biofilm degradation concentrations. After the incubation, the effect of enzymes on the bacterial growth checked, and the MIC and MBC (minimum bactericidal concentration) values were determined. The $\mathrm{MBC}$ value of an enzyme was considered as the lowest concentration of the enzyme that killed $99.9 \%$ of the bacterial cells [38]. Each experiment was carried out three times for all strains.

Determination of minimum inhibitory concentration (MIC) and minimum biofilm eliminating concentration (MBEC)

The MIC of amikacin (Sigma Aldrich, St Louis, USA) and ceftazidime (Jaber Ebne Hayyan Co, Iran) for the six sensitive selected strains was evaluated by broth microdilution method (antibiotic concentrations ranging from, 0.5 through $256 \mu \mathrm{g} \mathrm{mL}^{-1}$ ) according to the CLSI guidelines [35]. Biofilms were established, and then each well was washed three times with normal saline to remove unbound bacteria to determine the MBECs of amikacin and ceftazidime for biofilm cultures. Subsequently, $100 \mu \mathrm{L}$ of a given antibiotic concentration in cation-adjusted Muller-Hinton Broth was added to each well [39]. The plate was incubated at $37 \mathrm{C}$ for $20 \mathrm{~h}$, followed by adding $50 \mu \mathrm{L}$ of fresh XTT labeling mixture [2,3-bis[2-methyloxy-4-nitro-5sulfophenyl]-2H-tetrazolium-5-carboxanilide (XTT)] (Roche, Germany) to each well and incubated for $1 \mathrm{~h}$ at $37 \mathrm{C}$ under dark condition [40]. The MBEC value was determined as the lowest concentration of the antibiotic that inhibited the re-growth of bacteria from the treated biofilm [41].

\section{The effect of the combination of enzymes and ceftazidime on $P$. aeruginosa biofilms}

The combined effect of enzymes and ceftazidime on $P$. aeruginosa biofilms was determined as previously described $[42,43]$. The MBEC values of ceftazidime for biofilm cultures were determined by the XTT reduction assay.

\section{Cytotoxicity assay \\ Cell line and culture}

The cytotoxic effect of enzymes was investigated in A549 human lung carcinoma epithelial cell lines (IBRC C10080) and A-431 human epidermoid carcinoma cell lines (NCBI Code: C204).

\section{Cell viability assay}

Mitochondrial functions of the cells after $24 \mathrm{~h}$ exposure to the enzymes were evaluated by the XTT reduction assay. After $24 \mathrm{~h}$ exposure to the enzymes, specific amounts of XTT labeling mixture were directly added to the culture wells. After $4 \mathrm{~h}$ incubation in the dark conditions, the absorbance at $492 \mathrm{~nm}$ was measured with a microplate reader. In this study, control positive wells were cells with no enzyme exposure, and control negative wells contained a sterile medium. Each experiment was performed in duplicate.

\section{Statistical analysis}

Distributions of variables (ODs of biofilms) were evaluated using the Kolmogorov-Smirnov test. Since variables showed a non-normal distribution, a Wilcoxon Signed Ranks test was applied for comparison of ODs before and after treatment with enzymes and a Kruskal-Wallis test was used for determining the effects of enzymes on different $P$. aeruginosa strains. The differences between ceftazidime MBECs before and after using enzymes were evaluated using the Mann-Whitney $U$ test for each strain. A $P$-value $<0.05$ was considered statistically significant. All tests were performed using an online free available Graph Pad software (http://www.graphpad.com). 


\section{Supplementary information}

Supplementary information accompanies this paper at https://doi.org/10. 1186/s12866-019-1662-9.

Additional file 1. Supplementary data.

\section{Abbreviations}

CF: Cystic fibrosis; CFU: Colony forming units; CLSI: Clinical and Laboratory Standards Institute; CV assay: Crystal violet assay; KIA: Kligler Iron Agar; MBEC: Minimum biofilm eliminating concentrations; MIC: Minimum inhibitory concentration; OD: Optical density; OF: Oxidation-fermentation; PCR: Polymerase chain reaction; SEM: Scanning electron microscopy

\section{Acknowledgements}

Not applicable.

\section{Authors' contributions}

FJ and ME conceived and designed the experiments. MB, RF and NF performed the experiments. FJ, ME, RF, MB, RB, NF and WL analyzed the data. FJ, MB, ME, RF and WL wrote the manuscript. All authors reviewed and approved the manuscript.

\section{Funding}

The design of the study and collection, analysis, and interpretation of data, and writing the manuscript was supported by a grant (grant number: 97-0130/38043) from Tehran University of Medical Sciences to Dr. Fereshteh Jabalameli.

\section{Availability of data and materials}

All data generated or analyzed during this study are included in this published article [and its Additional files].

\section{Ethics approval and consent to participate}

The study protocol was approved by the Ethics Committee of Tehran University of Medical Sciences. Consent to participate is not applicable for this study because the isolates included in the study were obtained from existing clinical collections routinely assembled as part of laboratory practices of tertiary hospitals. The clinical strains of $P$. aeruginosa were obtained by permission of the head of hospital laboratory.

\section{Consent for publication}

Not applicable.

\section{Competing interests}

The authors declare that they have no competing interests.

\section{Author details}

${ }^{1}$ Department of Microbiology, School of Medicine, Tehran University of Medical Sciences, Tehran, Iran. ${ }^{2}$ Leiden Centre for Applied Bioscience, University of Applied Sciences Leiden, 2333CR Leiden, Netherlands.

Received: 8 July 2019 Accepted: 26 November 2019

Published online: 12 December 2019

\section{References}

1. Lyczak JB, Cannon CL, Pier GB. Lung infections associated with cystic fibrosis. Clin Microbiol Rev. 2002;15(2):194-222.

2. Rumbaugh KP, Griswold JA, Iglewski BH, Hamood AN. Contribution of quorum sensing to the virulence of Pseudomonas aeruginosa in burn wound infections. Infect Immun. 1999;67(11):5854-62.

3. Snarr BD, Baker P, Bamford NC, Sato Y, Liu H, Lehoux M, Gravelat FN, Ostapska H, Baistrocchi SR, Cerone RP. Microbial glycoside hydrolases as antibiofilm agents with cross-kingdom activity. Proc Natl Acad Sci U S A. 2017;114(27):7124-9.

4. Baker P, Hill PJ, Snarr BD, Alnabelseya N, Pestrak MJ, Lee MJ, Jennings LK Tam J, Melnyk RA, Parsek MR. Exopolysaccharide biosynthetic glycoside hydrolases can be utilized to disrupt and prevent Pseudomonas aeruginosa biofilms. Sci Adv. 2016;2(5):e1501632.

5. Ryder C, Byrd M, Wozniak DJ. Role of polysaccharides in Pseudomonas aeruginosa biofilm development. Curr Opin Microbiol. 2007;10(6):644-8.
6. Banar M, Emaneini M, Satarzadeh M, Abdellahi N, Beigverdi R, van Leeuwen WB, Jabalameli F. Evaluation of mannosidase and trypsin enzymes effects on biofilm production of Pseudomonas aeruginosa isolated from burn wound infections. PLoS One. 2016;11(10):e0164622.

7. Wozniak DJ, Wyckoff TJ, Starkey M, Keyser R, Azadi P, O'Toole GA, Parsek MR. Alginate is not a significant component of the extracellular polysaccharide matrix of PA14 and PAO1 Pseudomonas aeruginosa biofilms. Proc Natl Acad Sci U S A. 2003;100(13):7907-12.

8. Germoni L, Bremer P, Lamont I. The effect of alginate lyase on the gentamicin resistance of Pseudomonas aeruginosa in mucoid biofilms. J Appl Microbiol. 2016;121(1):126-35.

9. Franklin MJ, Nivens DE, Weadge JT, Howell PL. Biosynthesis of the Pseudomonas aeruginosa extracellular polysaccharides, alginate, Pel, and Psl. Front Microbiol. 2011;2:167.

10. Yang L, Hengzhuang W, Wu H, Damkiær S, Jochumsen N, Song Z, Givskov M, Høiby N, Molin S. Polysaccharides serve as scaffold of biofilms formed by mucoid Pseudomonas aeruginosa. FEMS Immunol Med Microbiol. 2012;65(2):366-76.

11. Wei $Q$, Ma LZ. Biofilm matrix and its regulation in Pseudomonas aeruginosa. Int J Mol Sci. 2013;14(10):20983-1005.

12. Jennings LK, Storek KM, Ledvina HE, Coulon C, Marmont LS, Sadovskaya I, Secor PR, Tseng BS, Scian M, Filloux A. Pel is a cationic exopolysaccharide that cross-links extracellular DNA in the Pseudomonas aeruginosa biofilm matrix. Proc Natl Acad Sci. 2015;112(36):11353-8.

13. Bhatt P, Rathi KR, Hazra S, Sharma A, Shete V. Prevalence of multidrug resistant Pseudomonas aeruginosa infection in burn patients at a tertiary care Centre. Indian J of Burns. 2015;23(1):56.

14. Hall-Stoodley L, Stoodley P. Evolving concepts in biofilm infections. Cell Microbiol. 2009:11(7):1034-43.

15. Kalpana BJ, Aarthy S, Pandian SK. Antibiofilm activity of a-amylase from Bacillus subtilis S8-18 against biofilm forming human bacterial pathogens. Appl Biochem Biotechnol. 2012;167(6):1778-94.

16. Roy V, Meyer MT, Smith JA, Gamby S, Sintim HO, Ghodssi R, Bentley WE. Al2 analogs and antibiotics: a synergistic approach to reduce bacterial biofilms. Appl Microbiol Biotechnol. 2013:97(6):2627-38.

17. Fleming D, Chahin L, Rumbaugh K. Glycoside hydrolases degrade polymicrobial bacterial biofilms in wounds. Antimicrob Agents Chemother. 2017;61(2):e01998-16.

18. Taylor PK, Yeung AT, Hancock RE. Antibiotic resistance in Pseudomonas aeruginosa biofilms: towards the development of novel anti-biofilm therapies. J Biotechnol. 2014;191:121-30.

19. Nemoto K, Hirota K, Murakami K, Taniguti K, Murata H, Viducic D, Miyake Y. Effect of Varidase (streptodornase) on biofilm formed by Pseudomonas aeruginosa. Chemotherapy. 2003;49(3):121-5.

20. Eckhart L, Fischer H, Barken KB, Tolker-Nielsen T, Tschachler E. DNase1L2 suppresses biofilm formation by Pseudomonas aeruginosa and Staphylococcus aureus. Br J Dermatol. 2007;156(6):1342-5.

21. Frederiksen B, Pressler T, Hansen A, Koch C, Høiby N. Effect of aerosolized rhDNase (Pulmozyme ${ }^{\circledast}$ ) on pulmonary colonization in patients with cystic fibrosis. Acta Paediatr. 2006:95(9):1070-4.

22. Boyd A. Chakrabarty Aá. Role of alginate lyase in cell detachment of Pseudomonas aeruginosa. Appl Environ Microbiol. 1994;60(7):2355-9.

23. Alkawash MA, Soothill JS, Schiller NL. Alginate lyase enhances antibiotic killing of mucoid Pseudomonas aeruginosa in biofilms. Apmis. 2006;114(2):131-8.

24. $\beta$-Glucosidase from almonds. G4511 SIGMA. [https://www.sigmaaldrich. $\mathrm{com} /$ catalog/product/sigma/g4511?lang=en\&region=CA]

25. Lyticase from Arthrobacter luteus. L2524 SIGMA. [https://wwW. sigmaaldrich.com/catalog/product/sigma/l2524?lang=en\&region=CA.]

26. Chen $M, Y u$ Q, Sun $H$. Novel strategies for the prevention and treatment of biofilm related infections. Int J Mol Sci. 2013;14(9):18488-501.

27. Kaplan JB. Therapeutic potential of biofilm-dispersing enzymes. IntJ Artif Organs. 2009:32(9):545-54

28. Falabella AF. Debridement and wound bed preparation. Dermatol Ther. 2006;19(6):317-25

29. Ramundo J, Gray M. Enzymatic wound debridement. J W Ostomy Continence Nurs. 2008;35(3):273-80

30. Rosenberg L, Lapid O, Bogdanov-Berezovsky A, Glesinger R, Krieger $Y$ Silberstein E, Sagi A, Judkins K, Singer AJ. Safety and efficacy of a proteolytic enzyme for enzymatic burn debridement: a preliminary report. Burns. 2004; 30(8):843-50.

31. Demidova-Rice TN, Hamblin MR, Herman IM. Acute and impaired wound healing: pathophysiology and current methods for drug delivery, part 1: 
normal and chronic wounds: biology, causes, and approaches to care. Adv Skin Wound Care. 2012;25(7):304.

32. Püllen R, Popp R, Volkers P, Füsgen I. Prospective randomized double-blind study of the wound-debriding effects of collagenase and fibrinolysin/ deoxyribonuclease in pressure ulcers. Age Ageing. 2002;31(2):126-30.

33. Gawande PV, Leung KP, Madhyastha S. Antibiofilm and antimicrobial efficacy of DispersinB ${ }^{\oplus}$-KSL-W peptide-based wound gel against chronic wound infection associated bacteria. Curr Microbiol. 2014;68(5):635-41.

34. Jabalameli F, Mirsalehian A, Khoramian B, Aligholi M, Khoramrooz SS, Asadollahi P, Taherikalani M, Emaneini M. Evaluation of biofilm production and characterization of genes encoding type III secretion system among Pseudomonas aeruginosa isolated from burn patients. Burns. 2012;38(8):1192-7.

35. Clinical and Laboratory Standards Institute. Performance Standards for Antimicrobial Susceptibility Testing; Twenty-Fourth Informational Supplement. M100S; 2016. p. 62-4

36. Kaplan JB, Ragunath C, Velliyagounder K, Fine DH, Ramasubbu N. Enzymatic detachment of Staphylococcus epidermidis biofilms. Antimicrob Agents Chemother. 2004;48(7):2633-6.

37. Ziuzina D, Boehm D, Patil S, Cullen P, Bourke P. Cold plasma inactivation of bacterial biofilms and reduction of quorum sensing regulated virulence factors. PLoS One. 2015;10(9):e0138209.

38. Pridmore A, Burch D, Lees P. Determination of minimum inhibitory and minimum bactericidal concentrations of tiamulin against field isolates of Actinobacillus pleuropneumoniae. Vet Microbiol. 2011:151(3-4):409-12.

39. Amorena B, Gracia E, Monzón M, Leiva J, Oteiza C, Pérez M, Alabart J-L, Hernández-Yago J. Antibiotic susceptibility assay for Staphylococcus aureus in biofilms developed in vitro. J Antimicrob Chemother. 1999;44(1):43-55.

40. Pettit RK, Weber CA, Kean MJ, Hoffmann H, Pettit GR, Tan R, Franks KS, Horton ML. Microplate Alamar blue assay for Staphylococcus epidermidis biofilm susceptibility testing. Antimicrob Agents Chemother. 2005;49(7):2612-7.

41. Sepandj F, Ceri H, Gibb A, Read R, Olson M. Minimum inhibitory concentration (MIC) versus minimum biofilm eliminating concentration (MBEC) in evaluation of antibiotic sensitivity of gram-negative bacilli causing peritonitis. Perit Dial Int. 2004;24(1):65-7.

42. Tetz GV, Artemenko NK, Tetz W. Effect of DNase and antibiotics on biofilm characteristics. Antimicrob Agents Chemother. 2009;53(3):1204-9.

43. Martins M, Henriques M, Lopez-Ribot UL, Oliveira R. Addition of DNase improves the in vitro activity of antifungal drugs against Candida albicans biofilms. Mycoses. 2012;55(1):80-5.

\section{Publisher's Note}

Springer Nature remains neutral with regard to jurisdictional claims in published maps and institutional affiliations.

Ready to submit your research? Choose BMC and benefit from:

- fast, convenient online submission

- thorough peer review by experienced researchers in your field

- rapid publication on acceptance

- support for research data, including large and complex data types

- gold Open Access which fosters wider collaboration and increased citations

- maximum visibility for your research: over $100 \mathrm{M}$ website views per year

At $\mathrm{BMC}$, research is always in progress.

Learn more biomedcentral.com/submissions 